\title{
右側頭窩に発生した血管外皮腫例
}

\author{
竹本 坏司・山本 英一*·秋定 健 \\ 佐藤 幸弘・半田 徹 ・折田 洋造
}

\section{A Case of Hemangiopericytoma of the Right Temporal Fossa}

\author{
Takuji Takemoto, Takesi Akisada, Yukihiro Sato, \\ Toru Handa and Yozo Orita \\ (Kawasaki Medical School) \\ Hidekazu Yamamoto \\ (Kawasaki Hospital, Kawasaki Medical School)
}

\begin{abstract}
A case of hemangiopericytoma of the right temporal fossa is described. An 80-year-old female presented with a right temporal tumor. A CT scan revealed a scattered low density area with marked contrast when enhanced. Therefore, surgical resection of the tumor was performed. Histopathology of this tumor showed ovoid to spindle-shaped cells that around a sinusoidal vascular component that formed staghorn channels. Based on these findings the tumor was diagnosed as a hemangiopericytoma.
\end{abstract}

Key words: hemangiopericytoma, temporal fossa, staghorn channel

はじめに

血管外皮腫は，1942年に Stout と Murrayl) により血管系腫瘍の新しい概念として提唱され た疾患であり，血管の外膜細胞より発生し比較 的まれである。今回著者らは, 右側頭窩に発生 した血管外皮腫の 1 例を経験したので若干の文 献的考察を加え報告する.

\section{症例および経過}

症例 : 80歳, 女性.

主訴：右側頭部腫瘤

既往歷 : 高血圧 (70歳頃指摘される)

家族歴：特記すべき事なし.

現病歴：1990年 1 月右側頭部腫瘤に気付くも
放置していた。同年 7 月当院皮膚科にて生検術 を施行，良性血管腫疑いにて 8 月 7 日当科紹介 受診となった。外来にて経過観察を行っていた が，増大傾向を示したために1991年11月12日手 術目的にて入院となった。

入院時現症 : 右側頭部腫瘤と, $162 / 86 \mathrm{mmHg}$ と高血圧を示した以外異常なく, 一般検査所見 でも特に異常は認められなかった.

右側頭部腫瘤は, 最大径約 $9.5 \mathrm{~cm}$ で境界不 明瞭, 硬さは弾性硬で可動性はなく, 皮膚は健 常で圧痛が認められた(図 1 )。軽度の開口障害 がみられたが, 顔面神経麻痺は認めなかった。 頸部リンパ節は触知しなかった。 
放射線診断学的所見：頭部 CT (図 2 )では, 右側頭部に境界比較的明瞭で造影効果が著明な 腫瘍を認め, 内部には壊死を思わす低吸収域が 散在していた。また，腫瘍の増大によると思わ れる煩骨弓の外方への骨折と側頭骨の菲薄化が みられた，Gaシンチグラムでは，同部にびま ん性の集積の亢進を認めた(図 3 ).

手術時所見：11月26日全身麻酔下にて腫瘍摘 出術を施行した。まず，頸部より右外頸動脈を 同定し，血管テープをかけ，予想される大出血

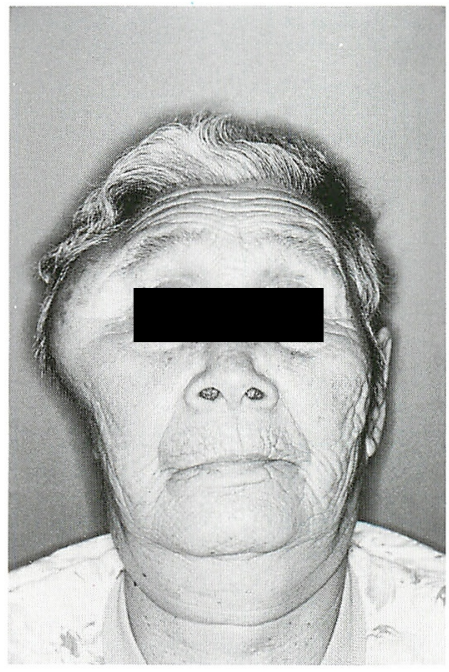

図 1 入院時颜写真

右側頭部に著明な腫脹が認められる

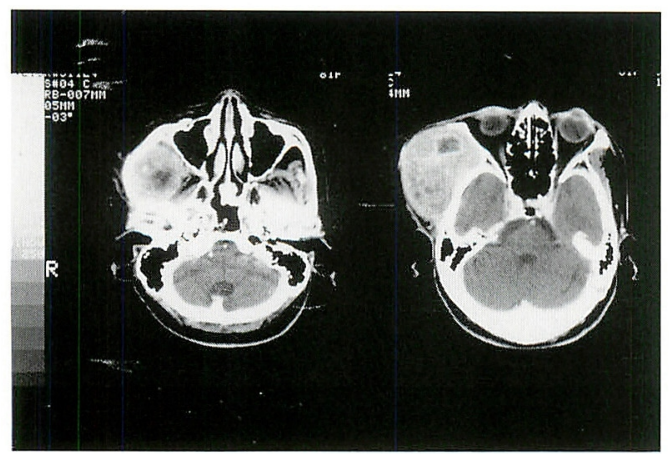

図 2 入院時 $\mathrm{CT}$

右側頭部に境界比較的明膫で造影効果が著明な腫 瘍を認める
に対処した。

次に，右耳前部より左前額部まで冠状切開を 加えた後, 皮切部に頭皮クリップをか恀鈍的に 剝離すると右側頭筋が希薄化した形で残存して いた．笳内への腫痬の明らかな浸潤は認めなか った。側頭筋を翻転すると，矢の直下に被膜に 覆われた楕円形, 弾性硬の腫瘍を認めた(図 4 ). 周囲との癒着は活とんどなく，鈍的剝離にて容 易に摘出できた。摘出標本は $7.5 \times 4.5 \times 4.5$ $\mathrm{cm}$, 充実性, 黄白色の腫瘍で, 所々に変性壊

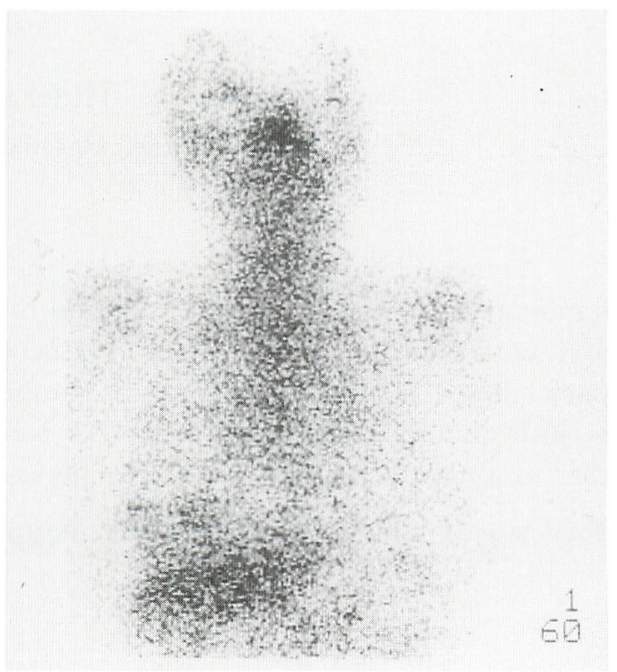

図 $3 \mathrm{Ga}$ シンチグラム

右側頭部にびまん性の集積の充進を認める

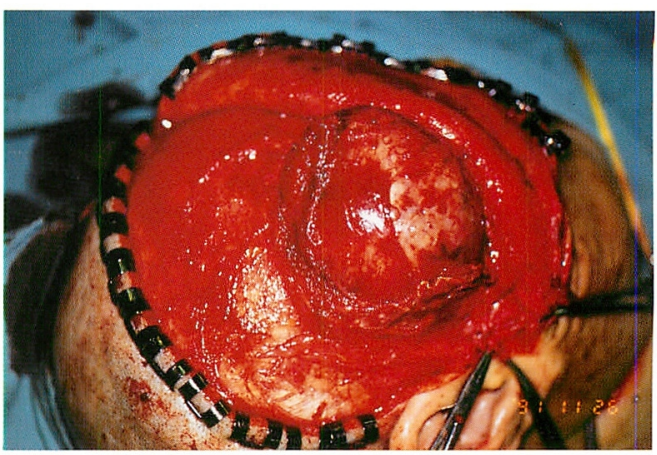

図 4 術中所見

側頭筋直下に被膜に覆われた楕円形，弾性硬の腫 瘍を認めた 
死がみられた（図５）。一部を迅速病理に提出す るも確定診断は得られなかった。頓骨弓は腫瘍 の内側からの圧迫により菲薄化し, 外側に弯曲 していたため，左右のバランスをとるために注 ぼ中心にて内側に折りまげた。側頭骨は蝶鱗縫 合を中心として約 $2 \mathrm{~cm}$ の範囲で骨膜が欠損し て拉り，この部分は易出血性であったが，骨臘 等で止血した。

病理学的所見：60倍の $\mathrm{HE}$ 染色標本では(図 6 ), 不規則に拡張した鹿の角様 (staghorn pattern) の間質血管周囲に類円形細胞の増殖が認 められた。免疫学的にラミニン染色(図 7 )を注 どこし毛細血管基底膜をみると，腫瘍細胞の増

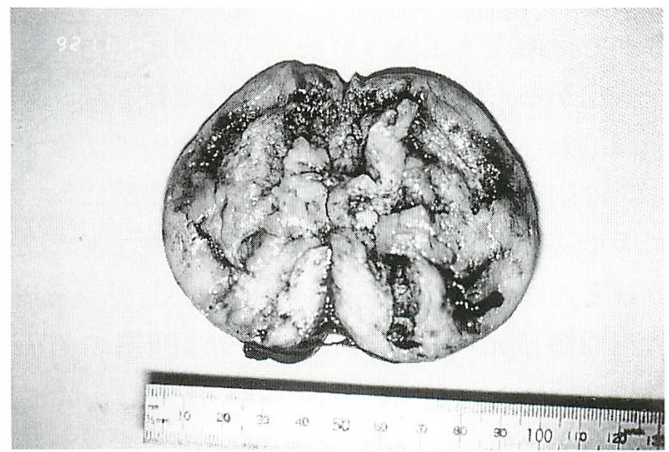

図 5 摘出標本

腫瘍は表面平滑で，割をいれると，所々に变性壊 死がみられた

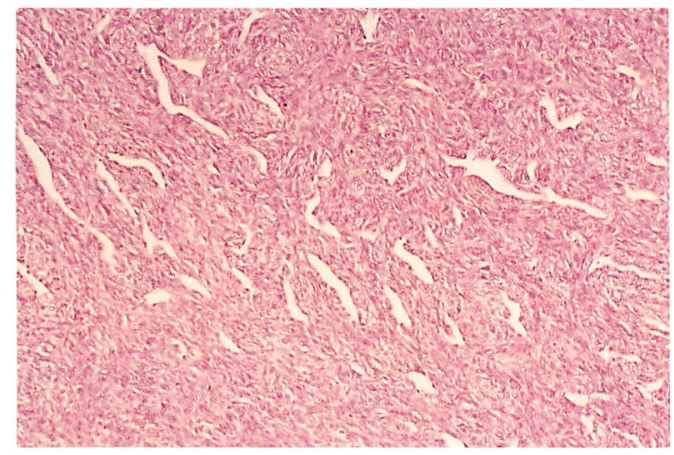

図 $6 \mathrm{HE}$ 染色標本

毛細血管の鹿の角様の変化 (staghorn pattern)が みられる
殖の強い場所でも圧排された多数の毛細血管が 観察された。

これは，血管内皮細胞は正常であり，血管外 皮細胞の増殖によって毛細血管が圧排されてい る事を示して沶り，以上より，本症例を血管外 皮腫と殓断した。

摘出時合併症として右顔面神経前額枝の不全 麻疾，また，腫瘍摘出後右側頭部の陥凹が認め られるものの, 現在外来にて経過観察中で, 局 所再発，転移はなく，経過良好である。

\section{考察}

血管外皮腫は，1942年に Stout と Murray に より血管性腫瘍の新しい概念として提唱された 疾患であり，血管周囲を取り巻く外膜細胞より 発生する腫瘍である11。

本腫瘍は全ての年齢層に発生をみているが, 杉原2) は，本邦例に扮いては，40歳以下の症例 が約 $60 \% ， 15$ 歳以下の症例が約 $18 \%$ と, 欧米の 報告に比べ若年層での発生率が高いと報告して いる。生下時発生例は, kaufmann ら ${ }^{3)}$ は301 例中 9 例, 本邦では101例中 6 例の報告がある. 性差は認められていない。

血管の外膜細胞より発生する本腫瘍は，身体 のいかなる部位にも発生し得るが，杉原2)は， 皮膚拈よび皮下組織原発が $56 \%$, 臓器原発が 44 \%と，皮膚拈よび皮下組織に好発すると報告し ている。また部位別でみると，下肢，頭頸部，

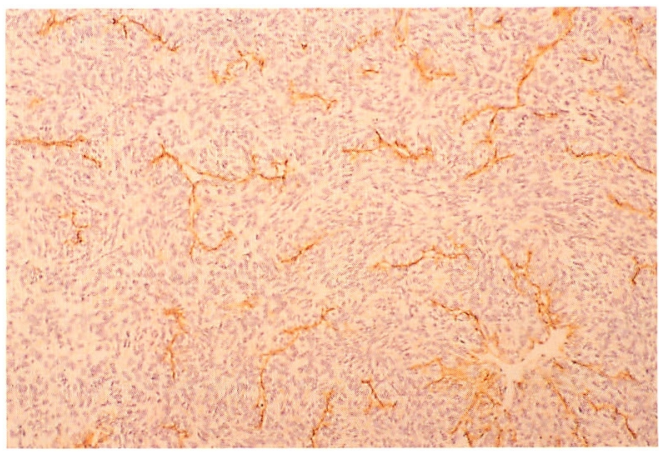

図 7 ラミニン染色標本

毛細血管の内皮細胞は，外皮細胞の腫瘍性増殖に より圧排されている 
上肢, 軀幹の順に多い，頭頸部の占める割合は $24 \%$ で, 欧文献も含めた田口4)の報告では, 頭 頸部発生のうちでは, 鼻・副鼻腔に発生したも のが最も多く90例中 21 例(約 $22 \%$ )であり, 次い で眼窩の 9 例 (10\%) とされている.

本腫瘍は, 多くは緩徐に増大寸る弾性硬の無 痛性皮下腫瘤として触れ，単発で限局性である. 臨床症状が非特異的であるため, 臨床診断はか なり困難である。画像診断においても5) 7), 1) 腫瘍内部の石灰化, 2) CT, 超音波にて, 腫瘍 が大きくなると壊死性哃胞を形成するため, 内 部構造は不均一に描出される, また, 造影 CT にて著明な造影効果を認める，3）血管造影に おいて, 毛細血管の拡張や腫瘍濃染像を認める, 等の特徵があげられているが, 特に本腫瘍に特 異的なものではない，自験例においては，CT にて, 造影効果が著明な腫瘍の内部に, 散在す る低吸収域を認めたが，明らかな石灰化はみら れなかった．血管造影は行っていない．また， $\mathrm{Ga}$ シンチグラムにて, 腫瘍に一致するびまん 性の集積の充進がみられたが，本腫瘍に対する 核医学の診断的価值はまだ確立されていない.

病理組織学的にみると, 本腫瘍の特徵は, 腫 瘍性血管の形成がみられず，不規則に拡張した 鹿の角様の間質血管 (staghorn pattern) 周囲に 腫瘍細胞の増殖が認められることである.腫瘍 細胞の核形は, 円形〜紡錐形, 楕円形と割合不 規則であり，核の大きさも大小不同で多核重複 しているものも認められる. 腫瘍細胞の配列は 多層性で，毛細血管と毛細血管の間を充満して おり，これら毛細血管を取り团むように配列し ている. 毛細血管腔は一層の内皮細胞に囲まれ ているが, 内皮細胞の存在しない部分もみられ る. 内皮細胞には異型性は認められない. 他の 腫瘍との鑑別には鍍銀染色が有用で, 同染色法 では毛細血管腔を囲むよらに好銀線維がみられ， その外側に腫瘍細胞が多層性に存在寸る. 腫瘍 細胞之腫瘍細胞之の間にも好銀線維が認められ， 腫瘍細胞は好銀線維で囲まれるように配列して いる。また，本腫瘍は臨床的に局所にとどまり，
切除後再発や転移をきたさない良性型と, 進行 が早く, 局所再発, 遠隔転移をきたす悪性型に 分類される. 一般に分裂像の多少, 壊死や出血 の有無, 細胞充実性の大小等により判断される が, この両者の病理学的鑑別は難しいとされて いる8).

Hemangiopericytomaは，レニン・アンギオ テンシン系の賦活による高血圧と低カリウム血 症9) や腫瘍内でのグルコース大量消費による低 血糖の発症が報告10)されている. 自験例にお いても70歳頃より高血圧がみられているが, 本 症との関連は明らかではない。

治療法としては腫瘍摘出, 放射線治療, 化学 療法等が試みられているが，健常な部分を含め た広範な外科的切除が第一選択とされている。

しかし, 頭頸部領域は解剖学的な問題もあり完 全摘出が不可能なことも多く, 特に鼻・副鼻腔 領域においては健常部分を大きく含めて切除す る事は困難であるため, 半数以上の症例におい て手術後の局所再発を認め, 遠隔転移などによ り注とんどの症例が 1 年以内に死亡している11). 放射線療法については, 伊藤111は腫瘍の縮小 効果は認めたとしているが，その効果は一定し ておらず，有効性は確立されていない。また， 化学療法についてもアクチノマイシンDが効果 を示した症例報告12) もあるが，大部分は無効 とされている.自験例では, 病理組織にて壊死 の存在と高い細胞密度により悪性の可能性が示 唆されたが, 術中所見にて腫瘍は被膜に覆われ ており完全摘出できた事，年齢的に80歳の高齢 である事を考光あわせ, 術後放射線や化学療法 等の追加治療は行わず, 退院, 経過観察とした。 現在, 術後約 1 年半を経過しているが, 明らか な再発は認められていない。

\section{まとめ}

80歳女性の右側頭窩に発生した血管外皮腫の 1 例を経験した．腫瘍は完全に摘出できたと考 え, 他の追加治療は行わずに経過観察とした. 本腫瘍は，局所再発や遠隔転移をきたしやすく， 定期的に観察することが望ましい。 
尚, 本論文の要旨は, 第 7 回中国頭頸部腫瘍研究 会(平成 4 年 6 月岡山)に拈いて発表した.

\section{参考文献}

1) Stout $\mathrm{AP}$ and Murray MR : Hemangiopericytoma; a vascular tumor featuring Zimmermanns pericytes. Ann Surg $116: 26 \sim 33,1942$.

2) 杉原平樹 : Malignant Hemangiopericytoma 臨 皮 $32: 769 \sim 776,1978$.

3) Kaufmann SL and Stout AP : Hemangiopericytoma in children. Cancer $13: 695,1960$.

4）田口喜一郎 : Radiation cancer を続発した喉頭 Hemangiopericytoma 症例. 耳喉 $41: 21 \sim 33$, 1974.

5) Goldman S, Davidson AJ and Neal J : Retroperitoneal and pelvic hemangiopericytomas ; clinical, radiological, and pathologic correlation. Radiology $168: 13 \sim 17,1988$.

6) Alpern MB, Thorsen MK, Kellman GM, et al : CT Appearance of Hemangiopericytoma. Journal of Computer Assisted Tomography $10: 264 \sim 267,1986$.
7) Enzinger FM and Smith $\mathrm{BH}$ : Hemangiopericytoma an analysis of 106 cases. Human Pathology $7: 1 ; 61 \sim 82,1976$.

8）長井克明：上䫇洞に発生した hemangiopericytoma $の 1$ 例. 耳鼻臨床 $76: 1050 \sim 1057,1983$.

9）横山久光：低K血症および若年性高血圧を合併 した眼窩腫瘍 Hemangiopericytomaによる異 所性 renin 産生腫瘍の 1 症例. 日内会誌 66 : 1568 1581, 1968.

10) Paullada JJ, Lisci GA and Gonzales AA : Hemangiopericytoma associated with hypoglycemia; metabolic and electron microscopic studies of a case. Am J Med 44 : 990 999, 1968.

11）伊藤 衛 : 鼻・副鼻腔に発生した Hemangiopericytoma の一例. 耳喉頭頸 $60: 125 \sim 129,1988$.

12) Wong PP : Chemotherapy of Hemangiopericytoma. Cancer $41: 1256 \sim 1260,1978$.

$$
\left(\begin{array}{l}
\text { 別刷請求先 : 竹本环司 } \\
\text { 干701-01 倉敷市松島 } 577 \\
\text { 川崎医科大学耳鼻咽喉科学教室 }
\end{array}\right)
$$

